\title{
Consumer's inflation expectations in Brazil ^
}

\author{
Fernando Ormonde Teixeira \\ Pesquisador - Fundação Getúlio Vargas (FGV) \\ Endereço: Rua Barão de Itambi, 60, $6^{\circ}$ andar - Botafogo - Rio de Janeiro/RJ \\ CEP: 22250-900 - E-mail: fernando.teixeira@fgv.br
}

\section{Ingrid Christyne Luquett de Oliveira}

Funcionária - Instituto Brasileiro de Geografia e Estatística (IBGE)

Endereço: Av. República do Chile, 500 - 10ªndar - Centro - Rio de Janeiro/RJ

CEP: 20031-170 - E-mail: ingrid.oliveira@ibge.gov.br

\section{Pedro Costa Ferreira}

Professor - Fundação Getúlio Vargas (FGV)

Endereço: Rua Barão de Itambi, 60, 60 andar - Botafogo - Rio de Janeiro/RJ

CEP: 22250-900 - E-mail: pedro.guilherme@fgv.br

Recebido: 05/07/2016. Aceite: 12/05/2017.

\begin{abstract}
This paper investigates what are the main components of consumer's inflation expectations. We combine the FGV's Consumer Survey with the indices of inflation (IPCA and government regulated prices), professional forecasts disclosed in the Focus report, and media data which we crawl from one of the biggest and most important Brazilian newspapers, Folha de São Paulo, to determine what factors are responsible for and improve consumer's forecast accuracy. We found gender, age and city of residence as major elements when analyzing micro-data. Aggregate data shows the past inflation as an important trigger in the formation of consumers' expectations and professional forecasts as negligible. Moreover, the media plays a significant role, accounting not only for the expectations' formation but for a better understanding of actual inflation as well.
\end{abstract}

\section{Keywords}

Inflation expectations. Media. Brazil. Consumers.

\section{Resumo}

O artigo investiga as principais variáveis que influenciam a formação das expectativas de inflação dos consumidores brasileiros. Combinamos sondagem do consumidor, divulgada pela FGV, índices de inflação (IPCA e preços regulados pelo governo), previsões do mercado para o IPCA publicadas no Boletim Focus e informações sobre a circulação de notícias de inflação em um dos maiores e mais importantes jornais nacionais, Folha de São Paulo, a fim de determinar fatores relevantes para previsão da inflação dos consumidores e melhoria da acurácia da mesma. A análise dos microdados da sondagem do consumidor identificou como principais variáveis o gênero, a idade e a cidade de residência. Dados agregados mostram a inflação passada como fator importante na formação das expectativas dos consumidores enquanto a previsão do

\footnotetext{
- Agradecimento ao Fundo de Pesquisa Aplicada da FGV-RJ.
} 
mercado não é significativa. Além disso, a mídia desempenha papel significativo, contando não apenas para a formação das expectativas como também para a melhora da compreensão sobre a inflação atual.

\section{Palavras-Chave}

Expectativas de inflação. Mídia. Brasil. Consumidores.

\section{Classificação JEL}

C22. D1. D84. E31. E52.

\section{Introduction}

Brazilian inflation trade-off debate in the past years and how it affects economy in the short and in the long run makes the understanding of how consumers frame their inflation expectations a crucial matter. In this study, we aim to understand how consumers form their inflation expectations. This can provide guidance to Central Banks and other government agencies so as to improve their management over the inflation rate. Economists have long understood that macroeconomic outcomes depend heavily upon agents' expectations. Since the 1970s the academic literature has sought to incorporate expectation in Macro models. More recent models started to take into account that agents may not be fully informed about all economic variables (Carroll 2003; Curtin 2007; Arora et al. 2013). Being able to anchor agents and mainly the consumers' expectations is a tool that no government can disregard.

The data used here come from the "Sondagem do Consumidor" (Consumer Survey) conducted by FGV/IBRE (Fundação Getulio Vargas - Getulio Vargas Foundation), the Brazilian Institute of Geography and Statistics, the Brazilian Central Bank and the Folha de São Paulo (FSP) newspaper. The consumer survey resembles deeply and was inspired by the Surveys of Consumers conducted by the Michigan University.

This study follows the framework proposed by Reis (2006) and Carroll (2003). We also attempt to partially replicate Easaw et al. (2012) and Campelo et al. (2014) in the Brazilian context by considering the media component as an important factor affecting consumers' behavior. To create the media variable, a crawler was used in FSP newspaper website, 
choosing phrases that were clearly related to inflation. We approach the subject using multiple econometric models, taking consumers' inflation expectations as the dependent variable and as explanatory variables a general inflation index, professional forecasts and the media variable, along with other controls.

We first look at micro data from the Consumer Survey by running an OLS model of inflation expectations against individual characteristics such as income, education, city of residence, age, gender and time fixed effects. We find out that gender, age, education, city of residence and income play major roles in explaining expectations. Also, time is a non-negligible factor as almost all of the time dummies are significant. These results, with an updated database, are in conformity with the previous findings of Campelo et al. (2014), reasserting our results.

As a third step, we run error correction models using aggregate data. We were able to reproduce some of the results found for other countries, showing that inflation has a short- and a long-term positive influence on expectations. Moreover, the inflation target is an anchor to consumers' expectation, while the media helps to reduce consumers' forecasting errors (Carroll 2003). The only result different from the previous literature was that professional forecasts have no significant effect on consumers' expectations (Easaw et al. 2012). However, this result is in accordance with Campelo et al. (2014).

There are four sections, the first being this introduction. Section 2 describes the data and the empirical strategy. Section 3 presents our results, emphasizing our main contribution, i.e., the inclusion of the media variable into the formation of inflation expectations. Finally, the fourth section draws conclusions and addresses the study limitations.

\section{Data}

The database comprises data from the FGV/IBRE Consumer Survey, the Brazilian Institute of Geography and Statistics (IBGE), the Central Bank (Bacen) and a web scrapping of the news from the biggest Brazilian newspaper, Folha de São Paulo, a newspaper with massive circula- 
tion in the country. The Consumer Survey is provided by the Getulio Vargas Foundation (FGV) in conjunction with the Brazilian Institute of Economics (IBRE) following research done in other countries such as the Surveys of Consumers conducted by the University of Michigan in the United States and the ISAE Consumers Survey in Italy. Since mid-2005, the monthly FGV/IBRE survey on consumer's opinions added a quantitative question about inflation expectations that allows us to replicate studies about consumers' inflation expectations seen in the USA and Europe. The media news information comes from a crawler written in the $R$ language, originating from the scan of the printed version of Folha de São Paulo newspaper. Information regarding the twelve month cumulative IPCA and the Focus report were harvested in the IBGE and Bacen websites, respectively. Both can be found in a monthly frequency and in a bigger time-span than needed, not requiring any kind of data manipulation.

The economic trend surveys are conducted continuously through time and generate vital information to enable monitoring and anticipation of events in the economy, providing timely tools to deal with aggregate economic variables. The insights brought by surveys allow policy makers to anticipate the directions to take in order to accommodate the short term economic course. The intuitions that emerge from the responses given about agents' decisions of spending and savings, extracting psychological behaviour, are impossible to be captured through classical approaches. The behaviour understanding improvement grants enhanced economic models. In spite of surveys being mostly about qualitative questions, FGV/IBRE introduced in its monthly research the quantitative query about consumers' inflation expectations and kept track of these expectations for more than a decade, which allows to deepen the knowledge about the subject.

Furthermore, directly following the conclusions found in Carroll (2003) and Ehrmann et al. (2015) paper, more media exposure about the "inflation" subject would lead to agents being better informed and, hence, with more accurate expectations the following months. To test these hypotheses, a "media variable" is created. This variable is not the same amongst the literature as Carroll computes an annual index of exposure based on The New York Times and the The Washington Post, whereas Ehrmann et al. (2015) use a monthly one and other authors create their own index (Carroll 2003; Lamla and Lein 2014; Ehrmann et al. 2015). A concern that has to be addressed is that the media may be biased in its reports which would generate distortions in expectation formations. 
The raw data harvested by the consumer's survey comprise a window going from December 2005 to February 2016, whereas the media data coming from FSP newspaper begins in 1999. This database can only be analyzed from June 2007 on, since before that date FSP did not widely adopt the internet as a media vehicle, which led to a sparse database. Thus, the definitive set of data constitutes 105 observations, which implies almost 9 years of collected information and a window big enough for this study, going from June 2007 to February 2016.

\section{a. Data handling and analysis}

\section{i. The Consumer Survey}

The survey conducted by FGV/IBRE brings to the surface crucial perceptions of agents following the Likert scale. This scale presents itself with five different answers and three different types of sentiments expressions, or levels. Results can be characterized as positive, neutral or negative following what the respondents reckon about an addressed issue. Also, the survey provides information about income, city of residence, education, age and gender (cf. Table 3 ) and the respondents are identified according to the specifications provided by FGV/IBRE, being preferably the householder and mandatorily of full legal age. Respondents are contacted by telephone and are part of a FGV/IBRE consumers' pool. As previously stated, the Consumer Survey brings more qualitative than quantitative information, the question: "In your opinion, what will be the Brazilian inflation in the next 12 months?" (Translated from: "Na sua opinião, de quanto será a inflação brasileira nos próximos 12 meses?") being the single question requiring a quantitative answer. The envisaged answer is given in percentage amounts and does not assume negative values or values bigger than $500 \%$. These cut-off points were arbitrarily chosen because they are in conflict with the inflationary levels observed since the advent of the Real currency in 1994, which suggests a misunderstanding of the question.

Table 1 presents the consumption distribution divided into geographic zones and income and should be read as following: Belo Horizonte is responsible for $6.60 \%$ of the total consumption in Brazil and the households with income up to $\mathrm{R} \$ 2100$ represent an amount of $24.09 \%$ of the country 
consumption. The information presented in this table is the survey's sample foundation. Table 2 summarizes the first four statistical moments and a few other raw, trimmed and inflation data characteristics.

Consumers overestimate the real inflation level and this overestimation persists after we apply trimming techniques. Even looking at the data first quantile, the consumer's expectation is inflated when compared to the IPCA average. We understand that consumers are not necessarily thinking of the IPCA index when answering the question. This happens since the question in the survey does not make a direct link between the index and the answer asked. Consumers might form their expectations as the composition of two behaviors described in Easaw et al. (2012, 2013): "inattentiveness" and "anchoring". This behavior occurs since acquiring information bears costs and, therefore, agents do it discretely over time. Also, more important than the correct inflation prediction is the high correlation between the two series.

Table 1 - Consumption distribution for the target cities of the survey

\begin{tabular}{|c|c|c|c|c|c|}
\hline Geographic zone & $\begin{array}{l}\text { "Income 1- } \\
\text { up to } R \$ 2100 "\end{array}$ & $\begin{array}{l}\text { "Income 2- } \\
\text { R\$2100,01 to } \\
\text { R\$4800" }\end{array}$ & $\begin{array}{l}\text { "Income } 3 \text { - } \\
\text { R\$4800,01 to } \\
\text { R\$9600" }\end{array}$ & $\begin{array}{c}\text { "Income 4- } \\
\text { more than } \\
\text { R\$9600" }\end{array}$ & Total \\
\hline Belo Horizonte & 1,60 & 1,64 & 1,64 & 1,72 & 6,60 \\
\hline Brasília & 2,24 & 2,57 & 3,11 & 3,28 & 11,20 \\
\hline Porto Alegre & 1,16 & 1,37 & 1,45 & 1,45 & 5,43 \\
\hline Recife & 0,71 & 0,71 & 0,67 & 0,67 & 2,76 \\
\hline Salvador & 1,79 & 1,37 & 1,16 & 1,00 & 5,32 \\
\hline Rio de Janeiro & 6,26 & 6,88 & 6,51 & 6,26 & 25,91 \\
\hline São Paulo & 10,33 & 10,58 & 10,08 & 11,79 & 42,78 \\
\hline Brazil & 24,09 & 25,12 & 24,62 & 26,17 & 100,00 \\
\hline
\end{tabular}

Source: Household Budget Survey (POF) 
Table 2 - Inflation Expectation of Brazilian Consumers, 2007-2016

\begin{tabular}{lrrrr}
\hline & No Trimming & \multicolumn{1}{c}{ Trimming Boxplot } & \multicolumn{1}{c}{ Trimming Percentil } & \multicolumn{1}{c}{ IPCA } \\
\hline Mean & 8,85 & 7,28 & 7,74 & 6,09 \\
Median & 8,39 & 7,02 & 7,43 & 5,91 \\
Std Dev & 0,18 & 0,12 & 0,13 & 0,15 \\
\hline Std Error & 0,02 & 0,02 & 0,02 & 0,02 \\
Q1 & 7,77 & 6,59 & 6,95 & 5,10 \\
\hline Q3 & 9,48 & 7,60 & 8,06 & 6,52 \\
Max & 14,67 & 11,49 & 12,67 & 10,71 \\
\hline Min & 5,94 & 5,04 & 5,45 & 3,69 \\
Kurtosis & 2,17 & 2,93 & 3,16 & 1,44 \\
\hline Skewness & 1,50 & 1,59 & 1,75 & 1,21 \\
Obs. & 105,00 & 105,00 & 105,00 & 105,00 \\
\hline
\end{tabular}

Source: Authors

Equation 1 shows the individual inflation expectation for the next 12 months, expressed as $\mathrm{E}_{\mathrm{t}}^{\mathrm{h}}\left(\pi_{\{\mathrm{t}+12\}}\right)$; where $h$ represents the individuals and $t$ represents current time. As stated before, individuals are selected from a pool of consumers, which means that individuals do not answer the survey every month and, as a consequence, the data are not panel but a cross-section repetition. Equations 1 and 2 were modelled so as to capture each individual characteristic effect studied ${ }^{l}$ to avoid the clear correlation between variables (example: education and income).

$$
\begin{aligned}
& E_{\mathrm{t}}^{\mathrm{h}}\left(\pi_{\{\mathrm{t}+12\}}\right)=\alpha_{0}+\alpha_{\mathrm{k}} \mathrm{D}(\mathrm{k})_{\mathrm{t}}^{\mathrm{h}}+\epsilon_{\mathrm{t}}^{\mathrm{h}} \\
& \mathrm{E}_{\mathrm{t}}^{\mathrm{h}}\left(\pi_{\{\mathrm{t}+12\}}\right)=\alpha_{\mathrm{t}} \tau_{\mathrm{t}}+\alpha_{\{\mathrm{k}\}} \mathrm{D}(\mathrm{k})_{\mathrm{t}}^{\mathrm{h}}+\epsilon_{\mathrm{t}}^{\mathrm{h}}
\end{aligned}
$$

A number of $k$ dummy variables were created for each sociodemographic characteristic where $\mathrm{D}(\mathrm{k})=1$ if an individual has a certain characteristic and zero otherwise. Equation 1 shows $\alpha_{0}$ as the intercept whereas in Equation 2 this coefficient is switched for a temporal dummy. These

1 Results are similar in both models. The second model is a complication of the first. This is why we do not interpret the coefficients associated with model 1 . Nevertheless, results of model 1 can be seen in Table 3. 
coefficients represent the inflation expectations averages for the reference group in each period and are omitted from the results in Table 3. All omitted coefficients are highly significant and the reference group can be described as a male, with monthly income smaller than $R \$ 2,100$, primary school education, living in São Paulo and 35 years of age or less.

Table 3 shows in columns 1 and 2 two regression models that will be better described later, column 3 and 4 show the number of observations of each group and its percentage participation in the sample. The last column shows the averages of expected inflation of each sociodemographic group.

The expected inflation averages of each sociodemographic group being correlated, the interpretation of these results should be seen with caution, nonetheless we can assert that the group with higher inflation expectation in the sample is the one with at most primary school education.

Looking into the micro-data models, an observed characteristic that stands out lies in column (2) of Table 3. There is an upward linear trend related to consumers' age. It can also be seen as a concave function if we notice that consumers that are 60 years old or more have slightly smaller expectations when compared to those between 35-44 years old. An explanation of this particular behavior might be that there is a rise in the number of retirees in the 45-60 years old window and that retired people may have more time to look at prices. Reported inflation is affected by personal experience (Curtin 2007), explaining the lower average. Education and income show a negative correlation with inflation expectations. The consumers' city of residence show mixed signals, Brasília being the only not statistically different from São Paulo and Rio de Janeiro and Porto Alegre showing higher average expectations. 
Table 3 - Micro-data Models

\begin{tabular}{|c|c|c|c|c|c|}
\hline \multicolumn{6}{|c|}{ Consumer_t } \\
\hline & (1) & (2) & Observations & $\%$ Participation & Avg. \\
\hline$<R \$ 2100$ & & & 25091 & 16,06 & 9,82 \\
\hline$>R \$ 2100$ e $\leq R \$ 4800$ & $-0,809^{\star * *}$ & $-0,948^{* \star *}$ & 37104 & 23,74 & 8,89 \\
\hline$>R \$ 4800$ e $\leq R \$ 9600$ & $-0,984^{* * *}$ & $-1,201^{* * *}$ & 42986 & 27,51 & 8,65 \\
\hline$>R \$ 9600$ & $-1,688^{\star \star *}$ & $-1,959^{\star * \star}$ & 51072 & 32,69 & 7,94 \\
\hline Primary School & & & 12943 & 8,28 & 10,04 \\
\hline High School & $-0,359^{* \star *}$ & $-0,393^{\star \star \star}$ & 42491 & 27,19 & 9,16 \\
\hline Undergraduate & $-1,200^{\star \star \star}$ & $-1,101^{\star * \star}$ & 60442 & 38,68 & 8,08 \\
\hline Graduate & $-0,463^{\star \star *}$ & $-0,945^{\star \star *}$ & 40377 & 25,85 & 8,57 \\
\hline São Paulo & & & 69456 & 44,45 & 8,59 \\
\hline Rio de Janeiro & $0,440^{* * *}$ & $0,335^{\star \star \star}$ & 34695 & 22,20 & 9,22 \\
\hline Belo Horizonte & $-0,161^{*}$ & $-0,182^{* *}$ & 12577 & 8,05 & 8,28 \\
\hline Brasilia & 0,016 & $-0,111$ & 15275 & 9,78 & 8,24 \\
\hline Salvador & $-0,365^{\star * *}$ & $-0,339^{* * *}$ & 7041 & 4,50 & 8,34 \\
\hline Porto Alegre & $0,733^{\star \star \star}$ & $0,803^{\star \star \star}$ & 9389 & 6,01 & 9,41 \\
\hline Recife & $-1,175^{\star \star \star}$ & $-0,924^{\star \star \star}$ & 7820 & 5,01 & 7,63 \\
\hline$<35$ years & & & 20289 & 12,98 & 7,39 \\
\hline$\geq 35 e<45$ years & $1,275^{\star \star \star}$ & $0,832^{\star \star *}$ & 27888 & 17,85 & 8,52 \\
\hline$\geq 45 e<60$ years & $1,795^{\star \star \star}$ & $1,053^{* * *}$ & 61176 & 39,15 & 8,97 \\
\hline$\geq 60$ years & $1,882^{* * *}$ & $0,874^{\star \star \star}$ & 46900 & 30,02 & 8,90 \\
\hline Mean & & & 82525 & 52,81 & 8,12 \\
\hline Women & $1,011^{\star * *}$ & $1,191^{\star \star \star}$ & 73728 & 47,19 & 9,26 \\
\hline Constant & $8,326^{* * *}$ & & & & \\
\hline$N$ & 153,253 & 156,253 & & & \\
\hline$R^{2}$ & 0,015 & 0,472 & & & \\
\hline Adjusted $R^{2}$ & 0,014 & 0,471 & & & \\
\hline
\end{tabular}

Notes: ${ }^{* * *}$ Significant at the 1 percent level

** Significant at the 5 percent level

*Significant at the 10 percent level

We monthly aggregate data to enable the observation of consumers' behavior as a whole throughout time. Figure 1 shows the expected inflations in $t$ period for 12 months ahead $(t+12)$ plotted with the inflation measured in 
period $t+12$. Figure 2 clearly shows that consumers overestimate inflation in their forecasts and that the expectation error of the professional economic agents (Focus) is smaller than the consumers' error, nevertheless it is also evident according to the data that professionals likely underestimate inflation.

Another factor brought up by Figure 1 is that there are movements in expectations that reduce the forecasts errors of consumers. Id est, consumers close the gap between their expectations and real inflation and also the professionals become less accurate. These movements are also perceptible in 2007/08 and 2010/11. A possible explanation for these two "bumps" shown in Figure 1 is the sub-prime crisis in United States that began in 2007 and arrived in Brazil in 2008 and the 2010/2011 US debt-ceiling along with the European crisis, when Greece threatened default and was rescued by the European Union. Since 2014, Brazil experiences its own internal political and economical crisis steepening the inflation increase movement that starts in 2013.

An alternative explanation is the rise in regulated prices inflation. Even though we did not plot, we ran the same exercise shown below to the CPI-R - regulated prices (we also tried the CPI related to food and beverages with no success). In 2010/11 and since 2014 until the end of the series the regulated prices are the major responsible for the CPI levels. The 2007/08 gap reduction would remain without explanation in this context.

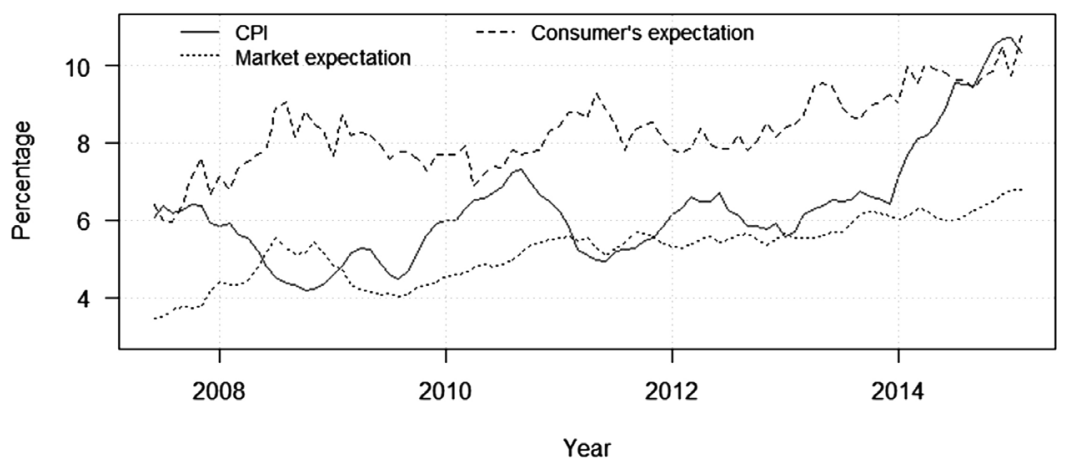

Figure 1 - Inflation Forecasts x IPCA

Source: Authors. 
Although the consumers' expectation error is, in absolute values, clearly bigger than the professionals' and that it is non negligible in percentage value, both expectations follow a similar trend as shows the Figure 2. Also, since the question in the consumer survey does not make any reference to the IPCA index, there is no direct mapping between consumers' expectations and the expectations disclosed by the professional forecasters.

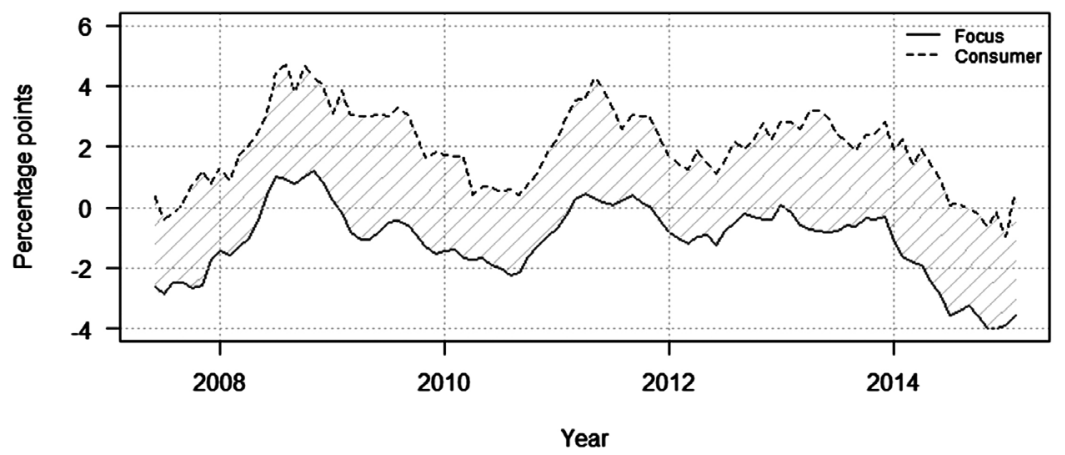

Figure 2 - Forecast Error Comparative

Source: Authors.

When we compare the correlation between series it seems clear that consumers generate their expectations for twelve months ahead just by looking at the inflation levels that they are experiencing at that date. The correlations are of $88 \%$ when we compare the expectations with actual inflation. That number falls sharply to a $25.8 \%$ when the comparison is drawn with the expectations and the twelve month ahead realized inflation.

A similar movement occurs in professional forecasts, with less intensity, dropping from $73.3 \%$ to $53.9 \%$. This behavior suggests a myopic vision from agents in their expectation formations and will be tackled further in this study. 


\section{ii. $\quad$ Media Data}

Data concerning news was captured through the website of the newspaper Folha de São Paulo. This newspaper was chosen because it is one of the most sold newspapers in the country, from the biggest Brazilian city and arguably the most important in social impact. The mixture of objective and subjective criteria is not ideal, but choosing based only on objective criteria could lead to tabloids, since there are a vast number of them circulating in the country and they sell more copies than the "traditional" newspapers, even though their social impact is almost irrelevant.

Media data capture was from only one newspaper because of technical limitations, but in accordance with literature (Carroll 2005). Each newspaper website requires different settings since they all work in different ways, restraining our possibilities. Our crawler, written in $\mathrm{R}$ programming language, accessed and stored all the online news on a daily basis. The phrases chosen to represent the concept of inflation in our study were "inflação" (inflation), "encarece" (more expensive), and combinations of the words "preço(s)" (price(s)) and "subiu", "subir(am)", "sobe(m)", "alta", "aument(a/ou/aram/am)" (rise(s), increase(s)). These words and expressions were empirically chosen looking at the contexts in which they are regularly applied and how often they are employed by the press.

The time series data available for each of these phrases can be seen in Figure 3 where there are three plot areas, one for each of the three groups researched. 

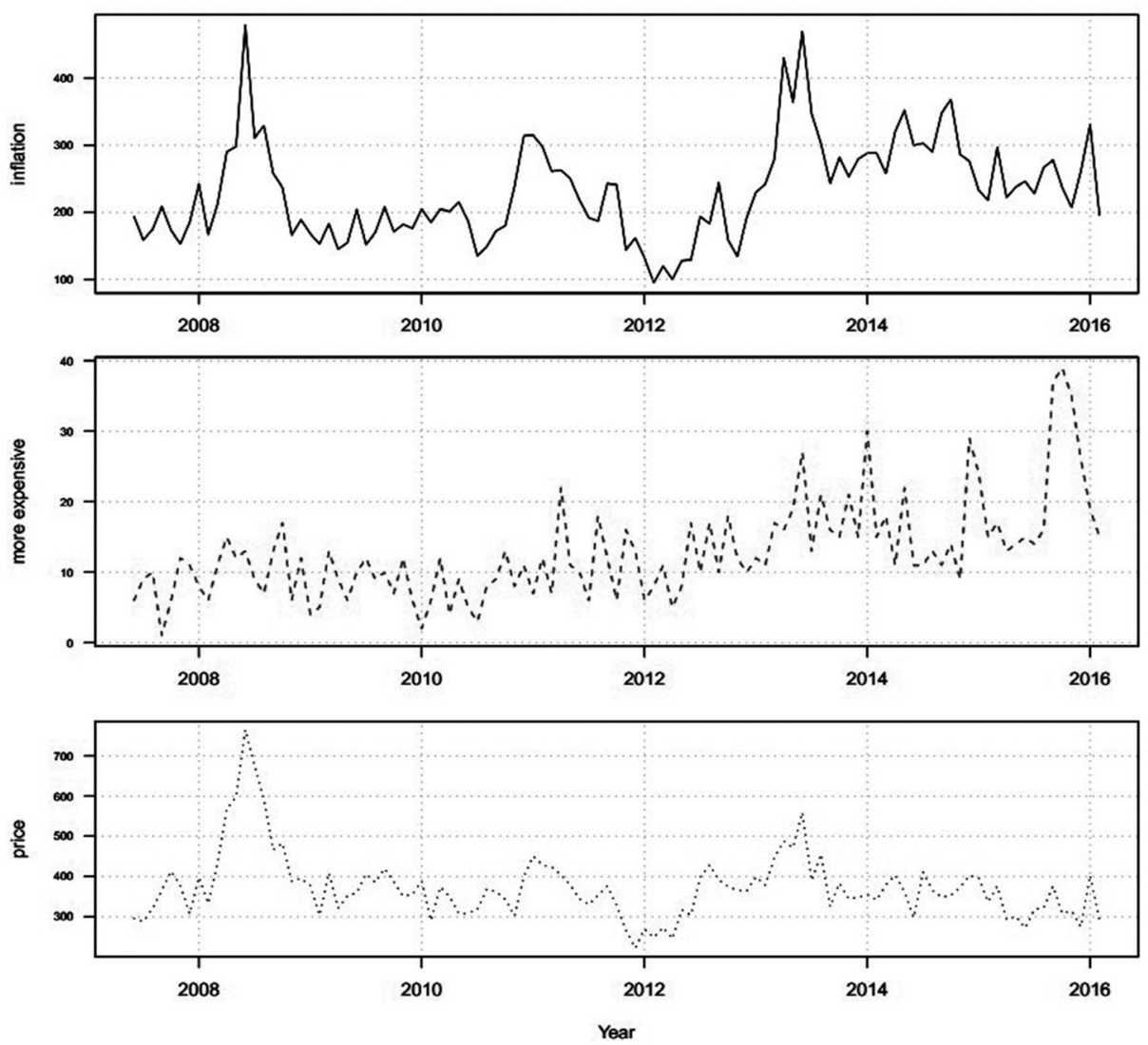

Figure 3 - Researched Expression

Source: Authors.

As we stated before, each news item containing the researched terms was catalogued for future consultation. The raw data are piled up in a database with the following columns: dates (day, month and year), the number of news items and a third column counting each term researched.

At first, we aggregated data monthly. Figure 4 shows the time-series of news and inflation news (we will refer to all three expressions as "inflation" from now on). Notice that the two lines are in different scales and that they do not follow a correlated path. Before 2007 there was a time window where the newspaper wasn't fully invested in its on-line product and that is why we shortened the series. 
The media variable created and tested is a proportion dummy, this kind of variable takes into account that there was an increase in the total number of monthly news items through time. This increase would bring challenges if we used the raw numbers. There are changes in the total number of news items through time in the online newspaper, but the news' ratios of specific themes should not suffer variations, ceteris paribus. As we only have one source of media information and considering that newspapers are local compared to other medias, like TV stations, we might incur a bias. Nonetheless, the online newspapers are more likely to target a national audience than their printed counterparts and, FSP being arguably the more respected and read along with $\mathrm{O}$ Globo and O Estado de São Paulo, this bias should not interfere with results.

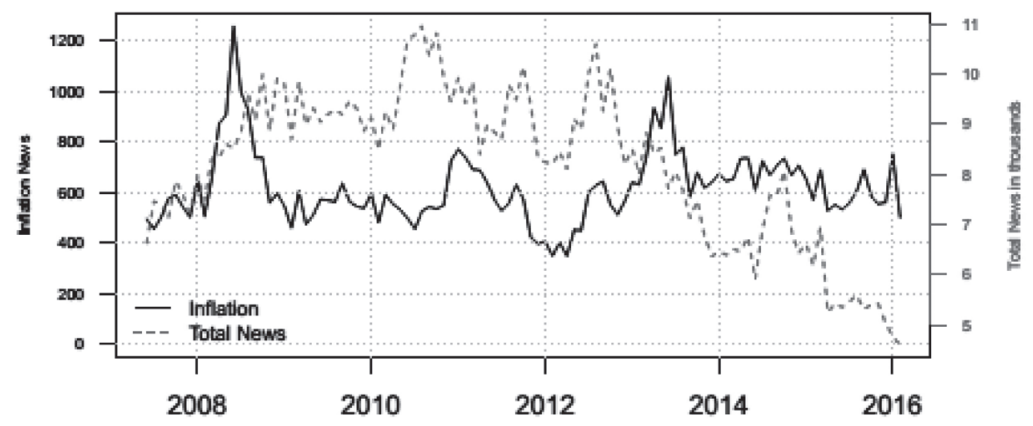

Figure 4 - News Captured

Source: Authors

The dummy is created to measure the impact of the news inflation in the total number of news items using the 85 th quantile. The dummy assumes a value of 0 when it is below the 85 th quantile of the series and 1 otherwise. The theory that supports the creation of this variable is that people more exposed to inflation news are more likely to get a better picture of the macroeconomics and, thus, form more accurate expectations. We do not yet have ways to measure how consumers absorb this news, if they absorb it. Besides, it would be interesting to measure if the media biases consumers. In other words, we expect that when the media reports more about inflation the consumers' forecast absolute error decreases if the media is unbiased, meaning that the news is consistent with what really is happening. 


\section{Model and results}

The models presented previously, with raw data about individuals through time have temporal limitation. This means that dynamic analyses are impossible since there is no guarantee that the same interviewee will be present throughout time (no respondent shows up throughout all the time period). This peculiarity forbids the use of "persistent information" expectations or epidemiological models and, even though we know that the groups heterogeneity might create bias in the aggregated series (Easaw et al. 2012), it rests clear that no group in the sample has characteristics so different and striking that would allow it to bias the series as a whole.

For these new models, we call the consumers' average inflation expectations 12 months ahead as Consumer, the 12 month cumulative inflation measured by IBGE is named as IPCA (national index of the broad consumer), the professional expectations average released by the Brazilian Central Bank is the Focus, and the dummy variable to capture media, Media.

We tested the regulated prices (prices managed by the federal government as it has control over these markets) and household debt as variables. These variables were exhaustively repeated in "focal groups" (these are control groups where pilot research is applied) promoted by FGV/IBRE as being the most important for their expectation formation. The regulated prices did not present themselves as a better proxy for inflation, hence we kept IPCA as our variable of choice. More information about why the IPCA showed itself as a better variable will be further discussed. Moreover, the debt variable did not show statistical significance, which means that we do not have enough evidence to reject the null hypothesis and, thereafter, debt does not affect consumers' inflation expectations formation.

The model presented in equation 3 attempts to reproduce those observed in Campelo et al. (2014), Easaw et al. (2012) and Malgarini (2009).

$$
\begin{aligned}
\Delta \text { Consumer }_{t} & =\beta_{1} \Delta \text { IPCA }_{\{t-1\}}+\beta_{2} \Delta \text { Focus }_{t}+\gamma\left(\text { Consumer }_{\{t-1\}}-\varphi_{1} I P C A_{\{t-2\}}\right. \\
& \left.-\varphi_{2} \text { Focus }\{t-1\}_{-}-\varphi_{3} \text { Target }^{T}\right)+\theta_{1} \text { Media }+\theta_{2} \text { dummy_ }_{-} 2014+\epsilon_{t}
\end{aligned}
$$


In this equation, apart from the variables already depicted such as the Consumer, IPCA and Focus we added the inflation target as a part of the model, working as a constant since it remains unchanged through the period studied. The inflation target in Brazil is at $4.5 \%$ and its addition to the model follows the literature, as it is supposed to be an anchor for inflation expectations (Campelo et al. 2014; Easaw et al. 2012; Malgarini 2009; Strohsal et al. 2016). Moreover, $\epsilon_{\mathrm{t}}$ is representing the model errors.

The model (1) parameters $\beta_{1}$ and $\beta_{2}$ in Table 4 are to be read as short time adjustments of the consumers' inflation expectations for the inflation and professional forecast variables, respectively. The first presented model shows results that resemble those found in Campelo et al. (2014) since the professional forecasts do not affect the Consumer variable and the IPCA variable is significant. This result is not verified in Carroll (2001) where both variables are significant at $5 \%$. The coefficient $\beta_{1}$ statistically different from zero, points out a possible "myopic" consumer behaviour, for which we already had a clue when we compared correlations between the inflation forecast and the actual inflation in the previous section. The coefficient $\varphi_{1}$ turns out to be significant as well, indicating that the long term inflation is a factor too. Furthermore, the coefficient of the professionals is not significant in the long run, which can be verified looking at coefficient $\varphi_{2}$. The inflation target variable works as our constant, but we are not allowed to identify separate values for $\varphi_{3}$ and $\operatorname{Target}^{T}$, meaning that we are not able to verify whether $\operatorname{Target}^{T}$ is consistent with the inflation target of $4.5 \%$. We can only infer that there is an anchoring mechanism in place, since the coefficient $\varphi_{3}$ is positive and very significant.

The $\gamma$ coefficient brings a unique interpretation. If $\gamma=0$, then there is no long term effect of actual inflation, professional forecasts or inflation target on consumers' expectations. The speed of adjustment found is similar to the one found in Campelo et al. (2014), being 0.43 in our second model tested and 0.42 in their work. This 0.42 can be translated as a rate of mean reversion between the long run inflation expectations level and the actual level, the disequilibrium gap among the two variables is dissipated by $42 \%$ after a month.

The two coefficients $\theta_{1}$ and $\theta_{2}$ are dummies that show positive influence in the dependent variable when activated. The first dummy has already been portrayed, the "dummy_2014" is there simply to capture a possible trend in data from 2014 until the end of the series (February 2016). 
Table 4 - Error Correction Models

\begin{tabular}{|c|c|c|c|c|c|c|}
\hline & & & Depend & ent variable: & & \\
\hline & & & $\Delta C$ & onsumer $_{t}$ & & \\
\hline & Coefficient & Model (1) & Model (2) & Model (3) & Model (4) & Model (5) \\
\hline$\triangle I P C A_{t-1}$ & $\beta_{1}$ & $0,818^{\star \star \star}$ & $0,743^{\star \star \star}$ & $0,731^{\star \star \star}$ & $0,814^{\star \star \star}$ & \\
\hline$\Delta$ Focus $_{t}$ & $\beta_{2}$ & $-0,072$ & $-0,181$ & & & \\
\hline$\Delta$ Regulated $_{t-1}$ & $\beta_{1}^{\prime}$ & & & & & $0,241^{\star * *}$ \\
\hline Consumer $_{t-1}$ & $\gamma$ & $-0,396^{\star * *}$ & $-0,430^{\star * *}$ & $-0,422^{\star * *}$ & $-0,395^{\star * *}$ & $-0,254^{\star \star *}$ \\
\hline$\triangle I P C A_{t-2}$ & $\varphi_{1}$ & $0,797^{\star \star \star}$ & $0,709^{\star \star \star}$ & $0,748^{\star * *}$ & $0,846^{\star \star \star}$ & \\
\hline$\Delta$ Focus $_{t-1}$ & $\varphi_{2}$ & 0,160 & $-0,251$ & & & \\
\hline$\Delta$ Regulated $_{t-2}$ & $\varphi_{1}^{\prime}$ & & & & & $-0,224^{\star * *}$ \\
\hline Target $^{T}$ & $\varphi_{3}$ & $0,648^{\star *}$ & $0,640^{\star \star *}$ & $0,818^{\star \star *}$ & $0,765^{\star \star \star}$ & $1,614^{\star \star *}$ \\
\hline Media $_{t}$ & $\theta_{1}$ & & $0,352^{\star \star *}$ & $0,311^{\star \star *}$ & & $0,530^{\star \star *}$ \\
\hline dummy 2014 & $\theta_{2}$ & $0,521^{\star \star *}$ & $0,492^{\star \star *}$ & $0,563^{\star * *}$ & $0,564^{\star * *}$ & $0,317^{\star}$ \\
\hline Observations & & 103 & 103 & 103 & 103 & 103 \\
\hline$R^{2}$ & & 0,319 & 0,362 & 0,351 & 0,315 & 0,259 \\
\hline Adjusted $R^{2}$ & & 0,269 & 0,308 & 0,31 & 0,28 & 0,213 \\
\hline Residual Std. Error & & $0,488(\mathrm{df}=96)$ & $0,436(\mathrm{df}=95)$ & $0,435(\mathrm{df}=97)$ & $0,444(\mathrm{df}=98)$ & $0,465(\mathrm{df}=97)$ \\
\hline F Statistic & & $6,419^{\star \star *}(\mathrm{df}=7 ; 96)$ & $6,729^{\star \star \star}(\mathrm{df}=8 ; 95)$ & $8,730^{\star * *}(d f=6 ; 97)$ & $9,022^{* * *}(\mathrm{df}=5 ; 98)$ & $5,658^{\star \star \star}(\mathrm{df}=6 ; 97)$ \\
\hline
\end{tabular}

Note: $* p<0,1 ; \quad * * p<0,05 ; * * * p<0,01$

Since the Focus forecast is irrelevant to the model (2), we ran it again in model (3) dropping the variable and allowing us to create a robustness check. There are no major variable behavior changes, reaffirming the previous results. Model (4) is also run as a robustness check. We dropped the media variable to verify that the media is a key component and an important explanatory variable. The adjusted $R^{2}$ sharply increases when comparing the models with and without the media variable. This result suggests that the explanatory power of the media in consumers' expectations formation is non negligible. Also, we run a model (5) with regulated prices instead of the IPCA variable. The biggest change observed is in the long run regulated prices coefficient, showing a negative sign. This result is not congruent with theory and the regulated prices were dropped on behalf of the more thorough inflation index. 
To analyze the possible bias brought by the media we verify the effect of increased inflation news in the consumers' forecast errors. As we have observed a myopic behavior from consumers, we compare their responses to the news of the actual consumers' inflation expectations with the actual inflation. The comparison was made using the MAPE (mean absolute percentage error) metric. The MAPE has the advantage of both taking into account positive and negative errors and that it compares percentage error instead of real values. This is especially positive considering that inflation goes from under $4 \%$ in the beginning of our time frame and ends over $10 \%$ in 2016 since one percentage point error then represented a 25\% error and now it represents less than $10 \%$.

When comparing the MAPE between the periods with and without big media influence we notice a decrease in the forecast errors from $48 \%$ to $44 \%$, or 4 percentage points. This result, ratified by an analysis of variance test, points out that the media brings the right information to consumers, thus improving their expectations significantly.

We ran two models with the MAPE (that we will call the "gap" between expectation and what happened) as dependent variable. Thus, the gap variable is based on the consumer myopic behavior, comparing actual inflation to actual expectations. In the first one the media is our only explanatory variable and the second shows the media and the dummy we created since 2014. Results can be seen in Table 5. Unfortunately, even though the coefficients show an expected negative sign, results are not statistically different from zero, but we might presume that with more data points in a broader time span these results could turn themselves significant, thus ratifying the international results found in Carroll (2003). 
Table 5: Household accuracy when there is media coverage

\begin{tabular}{lcc}
\hline & \multicolumn{3}{c}{ Dependent variable: } \\
\cline { 2 - 4 } & \multicolumn{3}{c}{ Gap $_{t}$} \\
\hline Coluna1 & $(1)$ & $(2)$ \\
Mediat & $-3,235$ & $-4,024$ \\
dummy 2014 & $(4,428)$ & $(4,097)$ \\
\hline Constant & $-1,772$ & \\
\hline Observations & $(3,687)$ & $48,056^{* * *}$ \\
\hline$R^{2}$ & $48,375^{* * *}$ & $(1,599)$ \\
\hline Adjusted $R^{2}$ & $(1,737)$ & 105 \\
\hline Residual Std. Error & 105 & 0,009 \\
F Statistic & 0,012 & $-0,0003$ \\
\hline
\end{tabular}

Note: $* p<0,1 ; * * p<0,05 ; * * * p<0,01$

\section{Conclusions}

This paper revisits the database provided by the Consumer's Survey conducted by FGV/IBRE under the paradigm developed by Easaw et al. (2012) and the Campelo et al. (2014) discussion paper. It brings updated data, reinforcing previous results found and an analysis of the reaction of the Brazilian consumer to the media, something never done in the context of Brazil that we are aware of.

As we shed light on the raw data through our micro-data initial model, it was possible to better understand consumers' characteristics and confirm some results previously seen in other studies, like the role of gender in expectations formation. Data suggest women have, on average, higher expectations than men, also income plays a major role as a negatively correlated variable. Age plays a positive factor, as people get older they tend to estimate inflation higher than their younger counterparts, except when consumers reach the age of 60 or more years old. There is a bump in the curve as the expectations slightly decrease compared to the previous age range (45-60 years). These numbers corroborate what was found in Campelo et al. (2014). 
Looking at the city of residence factor we see mixed signs as there are cities where people forecast smaller inflation rates than São Paulo and two that show consumers with higher expectations: Rio de Janeiro and Porto Alegre. We cannot determine if the regional expectations differences are the result of different regional inflation.

Aggregated data analysis showed that consumers adjust their expectations considering both the short and long term, which is a display that even if consumers are relatively "myopic" they do not completely erase the long term from their minds. This result is lined up with literature and other empirical studies. Another result found that is aligned with the literature is that consumers do not take into account professional forecasts as this variable is considered expensive to get.

The dummies we created to capture the effects of the media in the consumers' expectations formation and a trend on inflation since 2014 showed positive coefficients. The trend dummy result was expected since Figure 1 shows a big leap in inflation from 2014 on. The results that could not be anticipated were the ones of the effects of the media on the consumers' forecasts. Results showed that, not only media contributes to the formation of consumers' expectations, but that they subsidize people to better understand the inflation phenomenon, allowing them to reduce the gap between their expectations and the actual inflation.

Notwithstanding the advances brought by this paper in the Brazilian context, there are numerous possibilities that arise from studying this data in conjunction with other data sets that we did not explore. In particular, a more extensive and more detailed media database, with sources from multiple newspapers or incorporating news television stations. 


\section{References}

Arora, Vipin, Pedro Gomis-Porqueras and Shuping Shi. 2013. "The divergence between core and headline inflation: Implications for consumers' inflation expectations.” Journal of Macroeconomics 38: 497 - 504.

Campelo, A., et al. 2014. "Inflation expectations of Brazilian consumers: an analysis based on the FGV survey." Texto de Discussão 64. Instituto Brasileiro de Economia - Fundação Getúlio Vargas.

Carroll, Christopher D. 2001. "The epidemiology of macroeconomic expectations." National Bureau of Economic Research - Technical report 8695.

Carroll, Christopher D. 2003. "Macroeconomic expectations of households and professional forecasters." The Quarterly Journal of economics: 269 - 298.

Carroll, Christopher D. 2005. "The epidemiology of macroeconomic expectations." In The Economy as an Evolving Complex System, III: Current Perspectives and Future Directions, Edited by Lawrence E. Blume and Steven N. Durlauf. 2005.

Curtin, Richard. 2007. "What us consumers know about economic conditions." Paper presented at OECD World Forum.

Easaw, Joshy, Roberto Golinelli and Marco Malgarini. 2012. "Do households anchor their inflation expectations? Theory and evidence from a household survey." Acessed May 11, 2017. https://papers.ssrn.com/sol3/Delivery. cfm? abstractid=2136862.

Easaw, Joshy, Roberto Golinelli and Marco Malgarini. 2013. "What determines households inflation expectations? Theory and evidence from a households survey.” European Economic Review 61: 1 - 13.

Ehrmann, Michael, Damjan Pfajfar and Emiliano Santoro. 2015. "Consumers' attitudes and their inflation expectations." Finance and Economics Discussion Series 15.

FGV/IBRE. 2005. "Sondagem do consumidor.” Acessed December 14, 2016. https://goo.gl/SstliN.

Lamla, Michael J., and Sarah Lein. 2014. "The role of media for consumers' inflation expectation formation." Journal of Economic Behavior \& Organization 106: 62-77. doi:10.3929/ethz-a-005640674.

Malgarini, Marco. 2009. "Quantitative inflation perceptions and expectations of Italian consumers." Giornale degli Economisti e Annali di Economia: 53 - 82.

R Development Core Team. 2015. "R: A Language and Environment for Statistical Computing." R Foundation for Statistical Computing. Vienna: Austria.

Reis, Ricardo. 2006. "Inattentive producers.” The Review of Economic Studies 73 (3): 793 - 821.

Strohsal, Till, Rafi Melnick and Dieter Nautz. 2016. "The time-varying degree of inflation expectations anchoring." Journal of Macroeconomics 48: 62 - 71. doi:10.1016/j.jmacro.2016.02.002. 